University of Louisville

ThinkIR: The University of Louisville's Institutional Repository

College of Arts \& Sciences Senior Honors

Theses

College of Arts \& Sciences

$5-2015$

\title{
The effects of international laws on modern day slavery.
}

Sadmira Ramic

University of Louisville

Follow this and additional works at: https://ir.library.louisville.edu/honors

Part of the Human Rights Law Commons, and the International Law Commons

\section{Recommended Citation}

Ramic, Sadmira, "The effects of international laws on modern day slavery." (2015). College of Arts \& Sciences Senior Honors Theses. Paper 36.

http://doi.org/10.18297/honors/36

This Senior Honors Thesis is brought to you for free and open access by the College of Arts \& Sciences at ThinkIR: The University of Louisville's Institutional Repository. It has been accepted for inclusion in College of Arts \& Sciences Senior Honors Theses by an authorized administrator of ThinkIR: The University of Louisville's Institutional Repository. This title appears here courtesy of the author, who has retained all other copyrights. For more information, please contact thinkir@louisville.edu. 
The Effects of International Laws

On Modern Day Slavery

By

Sadmira Ramic

Submitted in partial fulfillment of the requirements

for Graduation summa cum laude

University of Louisville

March, 2015 


\section{The Effects of International Laws on Modern Day Slavery}

\section{Introduction}

Thinking of billion dollar industries, human trafficking is not one that easily comes to mind. However, this form of slavery has exploded and is booming throughout the world (Bales, 2009). Everyday millions of people, including children, are being sold for sex, labor, or any other need of the trafficker (Gooey, 2008). Improvements have been made in raising awareness of this issue, creating supporting organizations, and drafting laws against human trafficking, but long stretch gap exists to have a large impact on combating this global issue, including the difficulty of research gathering and lack of implementation of laws.

It is first important to define what human trafficking is and what it includes. This is a critical part of the thesis because there are many misconceptions that surround it. Though trafficking or enslavement of humans has been around for centuries, it has only recently caught the attention of state governments' in modern times. While we have been gaining knowledge of this issue, there are still limitations and much unknown. In order to further our understanding of human trafficking, a globally unified definition needed to be established. This initiative of a global consensus on the definition of human trafficking began in 2000 when the UN General 
Assembly adopted the United Nations Convention Against Transnational Organized Crime. The protocol to Prevent, Suppress, and Punish Trafficking in Persons was a major progressive step for combating human trafficking. This protocol set a global definition of trafficking in persons as, "the recruitment, transportation, transfer, harbouring or receipt of persons, by means of the threat or the use of force or other forms of coercion, of abduction, of fraud, of deception, of abuse of power or of a position of vulnerability or of the giving or receiving payments or benefits to achieve the consent of a person having control over another person, for the purpose of exploitation” (Lee, 8). In addition, the protocol laid out that the consent of the victim is deemed irrelevant, that the crossing of borders is not a necessary requirement for this type of crime, and that the use of threat and deception are not necessary requirements when children are involved. This modern definition contradicts the standard definition of trafficking which requires movement or transportation of tangible things or persons.

While there has been an agreement on the global definition, accumulating data on trafficking events has continued to be unstable. For example, the Polaris Project has cited the International Labor Organization (ILO) statistics of 21 million victims of human trafficking globally (Polaris, 2015). This number underrepresents global trafficking of persons when you consider all the different types of human trafficking including sex trafficking, labor trafficking, organ harvesting, domestic servitude, and child trafficking. This discrepancy may not be intentional; the crime is often underreported or sometimes mislabeled, and some countries do not keep up with the research. Just because the exact numbers cannot be agreed upon, does not mean that human trafficking is not happening. While the numbers tend to fluctuate between different sources, it can be agreed that the number of victims is in the millions (Lee, 2011). There are 
many victims who speak out, seek help, and share their horrific stories of being one of these millions, and these are the stories that matter. The exact numbers should not undermine this.

\section{Case Examples}

In Romania, a young woman met a man who was a frequent customer at the coffee shop where she was employed. Through time they became friends, and eventually he wanted to marry her. After frequently visiting her home, he asked her parents to marry her and they moved to Italy. He introduced her to his "cousin” and forced her to prostitute herself through physical, emotional, psychological abuse (United Nations Office on Drugs and Crime [UNODC], 2015).

In Jordan, a man was coerced into selling his kidney. When he travelled to Iraq, his passport was confiscated. He was later "convinced" to encourage two other men to do the same. He was forced to return to Jordan without his passport and money. After falsely reporting his passport as lost, the authorities arrested him and charged him with selling his organs. The men who coerced him into committing the crime were never investigated nor arrested (UNODC, 2015).

In the United States, girls ages 14 and 17 from Cameroon were promised a job doing light house work and the ability to attend school. When they arrived in the United States, they were raped and physically and mentally abused repeatedly. They were forced to work long hours as servants and nannies, for which they were never paid (UNODC, 2015).

In many studies, there is a large focus on the numbers of victims and statistics, but it is anecdotal stories like these, and the many untold stories that should encourage countries around the world to take human trafficking seriously. It should not matter if there are 10 million victims or 500 thousand, a problem should be addressed. The cringing details of victims' stories are 
something no human should have to experience and that is a motivation in itself to punish and deter traffickers. While many countries have laws concerning human trafficking, these laws may not be implemented and/or they don't comply with the international laws (Abramson, 2003). It is very important to study not only the construction of the laws concerning human trafficking of different countries, but also how these laws are implemented, especially when considering the prosecution of the traffickers themselves. This study will aim to do just this.

This study will first review the international laws on human trafficking, and then it will briefly examine the laws of Bangladesh, Thailand, United Arab Emirates, and the United States. This approach will provide a broad perspective of international law and then specify how legislation of these four countries compare to each other. These four countries were chosen due to their tier placement according to the United States minimum standards; each country is placed in a different tier of 1 to 4 . The criterion for tier placement is explained later in this paper. The United Arab Emirates (UAE) was specifically chosen because of personal interest. When researching human trafficking, I was intrigued by the country’s leader's firm stance against human trafficking, especially camel jockeys, yet there is strong evidence that supports that UAE has improved trafficking legislation but not enforcement as related to young boys for the purpose of racing camels.

This study will examine the United Nations Office on Drugs and Crime (UNODC) case law database by reviewing each case from each country and collecting numerical data. This information will be used to answer how human trafficking laws are being implemented via punishment of the trafficker. The results are expected to show that the number of cases prosecuted remain relatively low although the creation of human trafficking laws are occurring internationally and domestically. 


\section{Literature Review}

\section{International}

There are many international instruments that address slavery, forced labor, and similar practices that date as far back as 1815 (Clawson, Dutch, Lopez, \& Tiapula,2008). Some of the instruments deal with general human rights, while others have a specific agenda. The Declaration of Human Rights (UDHR) was adopted by the UN in 1948, and falls into the category of general human rights. However, within UDHR is the Worst Forms of Child Labor Convention (WFCLC), also known as Protocol to Prevent, Suppress, and Prevent Trafficking in Persons (PPSPTP), which has a more specific agenda. The basic purpose of this protocol is to prevent and combat human trafficking, to protect and assist victims, and to promote international cooperation (Clawson et al., 2008). As mentioned above in the introduction, the Protocol established a global definition of trafficking in persons. In addition, Articles 9 through 13 laid out requirements for law enforcement agencies dealing with human trafficking. This includes the sharing of information, training, cooperation in identifying the traffickers, and providing proper security measures at borders.

More recently, the Council of Europe Convention on Action against Trafficking in Human Beings (CECATHB) was adopted in 2005. This treaty shares a similar purpose as the PPSPTP, but it focuses on countries within Europe (CECATHB, 2005).

\section{Bangladesh}

With the global definition as a stepping stone, countries began to construct their own laws that pertain to them. One of these countries is Bangladesh. Though the Prevention of Oppression Against Women and Children Act 2000 was not created to specifically target human 
trafficking, the influence of the protocol can be found under number 5 and number 6 of the Act. Number 5 deals with the trafficking of women and number 6 deals with trafficking of children. Unfortunately, the influence of the protocol stops there. It is clear that they created a punishment for trafficking of women and children, but they failed to adopt the above definition of trafficking. Instead they defined trafficking of women as "whoever fetches from abroad or dispatches or sends abroad for prostitution or, to engage a woman in illicit immoral act or sale or buy or, for the purpose of torturing her in rent or otherwise” (Harvard School of Public Health, 2). In other words, it seems that trafficking is dependent on prostitution taking place. The definition for child trafficking moves away from focusing on prostitution and instead it states that such action has occurred when one "fetches from abroad or dispatches or smuggles abroad a child for any illegal or immoral purpose, or sells or purchases or keeps a child in his possession, custody or security for such purpose” (3).

The punishments laid out for these offenses are vague and open to interpretation. For trafficking women, the punishment can range from 10 years to death, with no explanation of what requirements are needed to determine the appropriate sentencing. The punishment for trafficking a child is much stricter; it is life or death with an unspecified fine (3).

In addition to the specific laws applying to human trafficking, the constitution of Bangladesh, Section 34 (1) prohibits all forms of forced labor that does not involve punishment for a criminal offense and any kind of labor "required by law for public purposes" (Legislative and Parliamentary Affairs Division, 2010). In the same constitution under article 18 (2), the state is required to take effective measures to prevent prostitution. However, there is no explanation of what "effective measures” includes.

\section{Thailand}


Though Thailand took action years after the protocol, the Anti-Trafficking in Persons Act B.E 2551 came into effect in 2008 by labeling and defining human trafficking similarly to the protocol. The Act sought to include any activities in which the person was forced to participate in regardless of the victim's consent. Exploitation included sexual exploitation, such as pornography and prostitution, slavery, forced labor, and removal of organs for trade. Similar to the protocol, the Act stated that the persons did not have to be taken across borders for it to be considered trafficking. Specifically, the Act states that a person has committed trafficking when they are "procuring, buying, selling, vending, bringing from or sending to, detaining or confining, harboring, or receiving any person, by means of the threat or use of force, abduction, fraud, deception, abuse of power, or of the giving money or benefits to achieve the consent of a person having control over another person in allowing the offender to exploit the person under his control” (Protection Project, 3). Similarly, a person who supports or aids a trafficker, or assists in any way to prevent their arrest, or inducing someone to be part of a criminal group that involves human trafficking, is also guilty of trafficking in persons.

The punishment for someone who commits human trafficking hinges upon the age of a child, if one is involved. Anyone who commits human trafficking is imprisoned for 4-10 years and pays a fine of 80,000 Baht to 200,000 Baht (1 dollar is equivalent to 32.88 Baht). If the victim is a 15-18 year old child the punishment jumps to 6-12 years imprisonment and a 120,000- 240,000 Baht fine. If the victim is a child under 15 years old, the punishment increases to 8-15 years imprisonment and a 160,000-300,000 Baht fine. Though persons who attempt to commit human trafficking, aid the trafficker and assist in preventing their arrest are guilty of trafficking in persons, their punishment is less severe. For example, if they prepare to commit the offense, they are punished up to 1/3 of the sentence and fine set up for that offense. Also, if 2 or 
more conspire to commit the offense, they are punished up to $1 / 2$ of the sentence and fine for that offense.

\section{United Arab Emirates}

Like Thailand, the United Arab Emirates refers to human trafficking as it is defined in the protocol. In fact, their definition of it is taken directly from the protocol. In addition, sexual exploitation, prostitution, forced labor, slavery, servitude, and organ removal are all considered to be exploitation (Protection Project, 2010). The definitions and punishments for human trafficking are laid out in Federal Law 51. Under this law, anyone who commits the offense of human trafficking will be punished with imprisonment for no less than 5 years (National Committee to Combat Human Trafficking, 2006). A life sentence is handed down when the offense includes an organized criminal gang, the victim is a woman or handicapped child, "the perpetrator has committed an act by fraud, accompanied by use of force, threat to kill, to inflict grave harm or to use physical or mental torture," if two or more people are involved, the person who committed the crime was armed, the perpetrator is a spouse, a parent, a sibling, or someone who had control over the act, the crime is transnational, and if the perpetrator is a civil servant or is commissioned in the office (Article 2).Those who are not the perpetrator's spouse, sibling, parent, or child, and they have knowledge of the crime occurring and they did not report it to the authorities will be punished with 1-5 years imprisonment (Article 3). Persons who are involved in the crime, such as those that hide the perpetrator that has committed the crime and withholding information, will also face imprisonment (Article 4).

\section{United States}


The Trafficking Victims Protection Act (TVPA) is the main U.S. Federal Act that addresses human trafficking (Protection Project, 2012). The TVPA has been reauthorized four times since 2000 in order to address the growing awareness of the breadth of the issue. TVPA was first enacted in 2000, shortly after the protocol to Prevent, Suppress, and Punish Trafficking in Persons and addressed the broader issues of human trafficking as it adopted the legal definitions from the protocol. The main purpose of the TVPA was to deal with the growing problem of human trafficking by insuring punishment for the offenders and protection to the victims. It also allowed the United States to assist foreign countries with their efforts to combat this issue.

In the TVPA, punishment for human trafficking was increased from 10 years to 20 years. Similar to the other acts mentioned above, the offender can face life imprisonment if the offense includes kidnapping, aggravated sexual abuse, death, or an attempt of any of these, and if a child under 14 years of age is involved (TVPA, 2000). In addition, the offender faces an unspecified fine. Something that separates this act from the others is that it outlines restitution to the victim by the offender as another form of punishment. This can vary depending on the nature of the crime.

Another interesting aspect of this act is that it addressed other countries as well. For example, if a country is receiving economic assistance from the United States it must report the severity of human trafficking within its borders and present an assessment of what efforts the government is making to combat the issue (2000). Sanctions from the United States government can be applied to non-compliant countries. The TVPA uses a Tier Placement system to rank countries according to efforts to meet minimum standards of reducing human trafficking. 
The TVPA was reauthorized in 2003. The goal of the reauthorization was to enhance prevention of trafficking in persons, especially for persons abroad (TVPRA, 2003). This goal was to be accomplished by setting up programs that will target the issues of borders. This includes programs that would train border guards and officials on how to identify traffickers, television programs as an informative source of the dangers of trafficking, and materials to notify travelers that sex tourism is illegal. The act was also amended to provide better protection for trafficking victims. The amendments included cooperation between foreign governments and nongovernmental organizations and allowing the victim to bring a civil lawsuit against the perpetrator.

In 2005, the TVPA was again reauthorized to focus on domestic trafficking and to enhance prosecution of trafficking. This was to be achieved through the inclusion of antitrafficking and protection measures for women and children into humanitarian emergency assistance and program activities (TVPRA, 2005). New legal measures were taken as well. For example, if an unaccompanied, alien child is believed to be a victim of severe trafficking, the director of Refugee Resettlement can appoint a guardian ad litem to help them through the process.

This reauthorization sought to provide additional assistance to victims of this crime. The “Pilot Program,” was to be established in a foreign country, which would provide things such as counseling and shelter for the victims (2005).

In the reauthorization of the TVPA in 2008, the amendments focused on establishing and carrying out new programs to prevent and deter trafficking in persons, as well as increasing effectiveness and research of the programs. The reauthorization was not limited to this however. There were many provisions that changed the legal procedure of the offense. For example, the 
standard of proof for sex trafficking was lowered, so the prosecutor had to only prove that the defendant acted in "reckless disregard of the fact that such means [force, fraud, or coercion] would be used' (TVPRA, 29). Also, the government did not have to prove that the defendant knew that the victim was a minor, as long as he/she had an "opportunity to observe the minor" (26).

The Violence Against Women Reauthorization Act of 2013, the last reauthorization to the TVPA, mainly focused on enhancing judicial and law enforcement tools to help combat violence against women and children. One main legal change is that it allowed law enforcement to extend their jurisdiction abroad to prosecute U.S. citizens who have sexually exploited children.

It is evident that the United States, compared to the other countries, has been a leader when drafting the acts to help combat human trafficking. It is also the only country that mentions any measures that it will take to prevent the issue outside of its borders. This study will demonstrate those efforts in the following methods.

\section{Methods}

This is a non-experimental quantitative research design. Data was collected from cases presented on the United Nations Office of Drugs and Crime (UNODC) case law database (United Nations Office on Drugs and Crime [UNODC], 2015). The data base included 91 countries with a total of 1, 176 human trafficking cases. For each country and their cases six variables of information were gathered and entered into an Excel file. This includes the total number of cases, the number of guilty verdicts, the number of not guilty verdicts, the number of cases that were withdrawn or dismissed, other charges or proceedings, and finally the number of 
unknown verdicts. Cases were put in the "other charges or proceedings" section if the charges were not closely correlated with human trafficking e.g. harboring an illegal alien, a breach of workplace relations, etc. It also included appeals as well as civil cases, since these types of cases cannot render a guilty verdict. Guilty verdicts include human trafficking charges as well as those similar to human trafficking e.g. transporting a minor for prostitution, forced labor, involuntary servitude, and conspiracy and/or accomplice to commit any of these crimes. It is important to note that there are several defendants as well as charges in many cases. That said, if the defendant was charged with human trafficking and a lower/ unrelated charge, and he/she was found not guilty of human trafficking, but guilty of the lower charge, that case would be put in the not guilty section.

In addition the year range for the verdicts of each country was also given in order to get an understanding of the year that the first case was prosecuted, as well as the most recent year in which a case was prosecuted. In total, 1176 cases were reviewed from a total of 91 countries. In addition to the UNODC database, the tiers placement from the Trafficking in Persons Report of 2014 was reviewed for the most recent Tier assignment. Though laws on the domestic and international level are analyzed to gain a better understanding of how different countries have defined and punished human trafficking, there was no research of why these laws were constructed the way they were.

\section{Results}

A percentage of prosecuting a guilty verdict was calculated for the 91 countries. Guilty verdicts ranged from $0 \%$ to $100 \%$. The average rate for a Guilty verdict was $71 \%$. A total of 41 countries had a conviction rate below the average. Table 1 lists the countries and the percentage of Guilty verdict. Bangladesh is highlighted in Table 1 as one of the four countries of interest in 
this study. The median percentage for Guilty verdicts was $80 \%$ with 49 countries demonstrating below the median (see Figure 1).

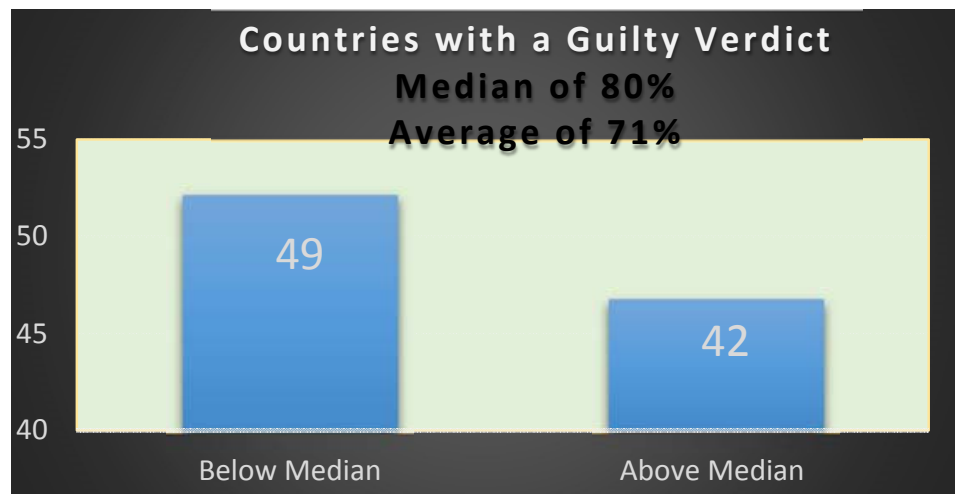

Figure 1

Countries with a Guilty Verdict Prosecution

Table 1

Countries below Average of $71 \%$ with a Guilty Verdict

\begin{tabular}{|c|c|c|c|}
\hline Country & \% Guilty Verdict & Country & \% Guilty Verdict \\
\hline France & $0 \%$ & Switzerland & $50 \%$ \\
\hline Bangladesh & $0 \%$ & El Salvador & $50 \%$ \\
\hline Malawi & $0 \%$ & Guatemala & $50 \%$ \\
\hline Mongolia & $0 \%$ & Mexico & $50 \%$ \\
\hline Singapore & $0 \%$ & Nepal & $50 \%$ \\
\hline Kenya & $11 \%$ & Portugal & $50 \%$ \\
\hline Nigeria & $15 \%$ & Canada & $55 \%$ \\
\hline South Africa & $17 \%$ & Finland & $63 \%$ \\
\hline Jamaica & $20 \%$ & Netherlands & $63 \%$ \\
\hline India & $23 \%$ & Brazil & $64 \%$ \\
\hline United Kingdom & $27 \%$ & Australia & $65 \%$ \\
\hline Japan & $33 \%$ & Belgium & $66 \%$ \\
\hline Jordan & $33 \%$ & Poland & $67 \%$ \\
\hline
\end{tabular}




\begin{tabular}{|l|c||c|c|}
\hline Malaysia & $33 \%$ & Sweden & $67 \%$ \\
\hline Russian Federation T3 & $33 \%$ & Fiji & $67 \%$ \\
\hline Panama & $33 \%$ & Belize & $67 \%$ \\
\hline Lithuania & $40 \%$ & China & $67 \%$ \\
\hline Bolivia & $43 \%$ & Czech Republic & $69 \%$ \\
\hline Italy & $50 \%$ & Bulgaria & $70 \%$ \\
\hline New Zealand & $50 \%$ & Peru & $71 \%$ \\
\hline Spain & $50 \%$ & & - \\
\hline
\end{tabular}

\section{Bangladesh}

Bangladesh was placed in the Tier 2 category. As it is mentioned above, the country has taken steps to criminalize trafficking in persons, but has yet to do much to punish the traffickers. This is evident in the data; they have only had 2 cases regarding human trafficking, one in 1997 and another in 2000. Even further, both of these cases resulted in a conviction other than human trafficking. Since the passing of the PPSPTP, there had been no evidence of any cases being pursued. Ultimately their guilty verdict was $0 \%$, which put them below the average and median.

\section{Thailand}

Thailand was placed in the Tier 3 category. This is despite a better record in the cases then Bangladesh; they have 12 cases of which 9 resulted in a guilty verdict and 3 resulted in convictions of other charges. The cases ranged from 2008 to 2013, which is obviously after the PPSPTP was passed. Their percentage of guilty verdicts was 75\%; which is below the median, but above the average. 


\section{United Arab Emirates}

There was no information gathered on the UAE because the UNODC case law database shows that they have pursued 0 cases.

\section{United States}

The United States is in the Tier 1 category and has had the most cases than any other country in the database. It had a total of 149 cases which ranged from 1981-2013. From these 149 cases, 112 resulted in a guilty verdict, 2 were not guilty, 9 were withdrawn or dismissed, 22 involved other charges or proceedings, and 1 remained unknown. With these numbers, the United States had a 75\% guilty verdict, which puts it above the average, but below the median.

\section{International}

The international court of justice website showed no cases for human trafficking.

\section{Tier Placement}

The U.S. Department of State has created tier placements in order to monitor and combat human trafficking. Countries are placed into these tiers based on their cooperation with the TVPA’s minimum standards. These minimum standards include, but are not limited to, having laws against human trafficking as well as punishment for it, "for the knowing commission of any act of sex trafficking involving force, fraud, coercion, or in which the victim of sex trafficking is a child incapable of giving meaningful consent, or of trafficking which includes rape or kidnapping or which causes a death, the government of the country should prescribe punishment commensurate with that for grave crimes," having punishment that will strive to deter future crimes as well as reflect the nature of the crime, and a serious effort is shown by the government that it is trying to eliminate severe forms of trafficking in persons (U.S. Department of State, 1). If the country fully complies with these standards, the country is placed in the Tier 1 category. If 
the country falls short of complying with these standards, but is making significant efforts to do so, it is placed in the Tier 2 category. The Tier 2 Watchlist category includes countries that are making efforts to comply with the minimum standards, but also have a significant increase in the absolute number of victims, failed to provide evidence that they are making significant efforts or they have determined that they will take the necessary efforts to combat human trafficking over the next year. Finally, the Tier 3 category includes countries that do not comply with the minimum standards and they are not making an effort to do so.

Tier 1 Placement. At the time of this UNODC data base, 27 countries were identified as meeting Tier 1 criterion. For the countries in the Tier 1 category there was an average of 18.07 cases. The United States is an outlier in Tier 1 with 149 cases of human trafficking of which 112 received a guilty verdict. The median for guilty verdict was 6 and the average was 13.1 (see Table 2). Of the 27 Tier 1 countries all had at least 1 guilty verdict. France had no guilty verdict of its 13 cases.

Table 2

Data for Countries in Tier 1

\begin{tabular}{|l|c|c|c|c|c|}
\hline \multicolumn{7}{|c|}{ Tier 1 Placement (N = 27) } \\
\hline Country & \#cases & Guilty & Not Guilty & Dismissed & Other Charges \\
\hline Armenia & 1 & 1 & 0 & 0 & 0 \\
\hline Australia & 20 & 13 & 2 & 1 & 2 \\
\hline Austria & 5 & 5 & 0 & 0 & 0 \\
\hline Belgium & 32 & 21 & 7 & 0 & 3 \\
\hline Canada & 11 & 6 & 2 & 0 & 2 \\
\hline Chile & 4 & 3 & 1 & 0 & 0 \\
\hline Czech Republic & 29 & 20 & 5 & 2 & 2 \\
\hline Denmark & 10 & 9 & 1 & 0 & 2 \\
\hline Finland & 8 & 5 & 1 & 0 & 10 \\
\hline France & 13 & 0 & 2 & 0 & 1 \\
\hline Germany & 24 & 22 & 1 & 0 & 0 \\
\hline Iceland & 1 & 1 & 0 & 0 & 2 \\
\hline Israel & 16 & 14 & 0 & 0 & \\
\hline
\end{tabular}




\begin{tabular}{|c|c|c|c|c|c|}
\hline Italy & 2 & 1 & 1 & 0 & 0 \\
\hline Macedonia & 4 & 4 & 0 & 0 & 0 \\
\hline Netherlands & 8 & 5 & 1 & 0 & 2 \\
\hline New Zealand & 2 & 1 & 0 & 1 & 0 \\
\hline Nicaragua & 6 & 6 & 0 & 0 & 0 \\
\hline Norway & 10 & 10 & 0 & 0 & 0 \\
\hline Poland & 21 & 14 & 2 & 1 & 4 \\
\hline Slovakia & 49 & 49 & 0 & 0 & 0 \\
\hline Slovenia & 1 & 1 & 0 & 0 & 0 \\
\hline Spain & 4 & 2 & 0 & 0 & 4 \\
\hline Sweden & 30 & 20 & 7 & 0 & 3 \\
\hline Switzerland & 6 & 3 & 2 & 0 & 1 \\
\hline United Kingdom & 22 & 6 & 1 & 1 & 14 \\
\hline United States & 149 & 112 & 2 & 9 & 22 \\
\hline MEDIAN & 10 & 6 & 1 & 1 & 1 \\
\hline AVERAGE & 18.07 & 13.1 & 1.4 & .56 & 2.74 \\
\hline
\end{tabular}


Table 3

Data for Countries in Tier 2

\begin{tabular}{|c|c|c|c|c|c|}
\hline \multicolumn{6}{|c|}{ Tier 2 Placement $(\mathrm{N}=45)$} \\
\hline Country & \#cases & Guilty & Not Guilty & Dismissed & Other Charges \\
\hline Albania & 17 & 16 & 1 & 0 & 0 \\
\hline Argentina & 65 & 55 & 10 & 0 & 0 \\
\hline Azerbaijan & 10 & 9 & 1 & 0 & 0 \\
\hline Bangladesh & 2 & 0 & 0 & 0 & 2 \\
\hline Brazil & 75 & 48 & 12 & 3 & 12 \\
\hline Bulgaria & 10 & 7 & 3 & 0 & 0 \\
\hline Colombia & 24 & 21 & 2 & 0 & 1 \\
\hline Costa Rica & 2 & 2 & 0 & 0 & 0 \\
\hline Croatia & 2 & 2 & 0 & 0 & 0 \\
\hline Ecuador & 1 & 1 & 0 & 0 & 0 \\
\hline Egypt & 4 & 4 & 0 & 0 & 0 \\
\hline El Salvador & 6 & 3 & 2 & 1 & 0 \\
\hline Estonia & 5 & 4 & 0 & 0 & 1 \\
\hline Fiji & 3 & 2 & 0 & 0 & 0 \\
\hline Georgia & 5 & 5 & 0 & 0 & 0 \\
\hline Guatemala & 8 & 4 & 3 & 0 & 1 \\
\hline Hungary & 6 & 5 & 0 & 0 & 0 \\
\hline India & 31 & 7 & 1 & 0 & 23 \\
\hline Indonesia & 10 & 9 & 1 & 0 & 0 \\
\hline Japan & 3 & 1 & 0 & 0 & 2 \\
\hline Jordan & 18 & 6 & 2 & 0 & 10 \\
\hline Kazakhstan & 4 & 4 & 0 & 0 & 0 \\
\hline Lithuania & 5 & 2 & 2 & 1 & 0 \\
\hline Malawi & 2 & 0 & 1 & 0 & 1 \\
\hline Mauritius & 1 & 1 & 0 & 0 & 0 \\
\hline Mexico & 2 & 1 & 0 & 1 & 0 \\
\hline Mongolia & 2 & 0 & 0 & 0 & 2 \\
\hline Mozambique & 1 & 1 & 0 & 0 & 0 \\
\hline Nepal & 2 & 1 & 1 & 0 & 0 \\
\hline Niger & 1 & 1 & 0 & 0 & 0 \\
\hline Nigeria & 13 & 2 & 4 & 0 & 7 \\
\hline Oman & 10 & 8 & 1 & 0 & 1 \\
\hline Palau & 1 & 1 & 0 & 0 & 0 \\
\hline Paraguay & 1 & 1 & 0 & 0 & 0 \\
\hline Peru & 7 & 5 & 0 & 0 & 1 \\
\hline Philippines & 61 & 60 & 0 & 0 & 1 \\
\hline Portugal & 4 & 2 & 1 & 0 & 1 \\
\hline Republic of Moldova & 60 & 44 & 13 & 0 & 3 \\
\hline Romania & 52 & 50 & 1 & 0 & 1 \\
\hline Serbia & 36 & 35 & 1 & 0 & 0 \\
\hline Singapore & 2 & 0 & 0 & 0 & 2 \\
\hline South Africa & 6 & 1 & 0 & 1 & 4 \\
\hline Togo & 1 & 1 & 0 & 0 & 0 \\
\hline Tonga & 1 & 1 & 0 & 0 & 0 \\
\hline Turkey & 11 & 10 & 1 & 0 & 0 \\
\hline MEDIAN & 5 & 3 & 0 & 0 & 0 \\
\hline AVERAGE & 13.18 & 9.84 & 1.42 & .16 & 1.69 \\
\hline
\end{tabular}


Tier 2 Placement. Forty-five countries met the criterion for Tier 2 placement with an average number of cases of 13.18 and average of 9.84 guilty verdicts (see table 3 on previous page). Bangladesh had 2 cases which were dismissed as other charges than human trafficking. Argentina, Brazil, Colombia, Indonesia, Oman, Philippines, Republic of Moldova, Romania, Serbia, and Turkey had a high success rate of guilty verdicts.

Tier 2 Watchlist Placement. For the Tier 2 Watchlist there were 14 countries with an average of 5.3 cases presented for prosecution (see Table 4). An average of 3.62 were found a guilty verdict for human trafficking. Ukraine on this list presented 21 cases and found a guilty verdict for 21 cases.

Table 4

Data for Countries in Tier 2 Watchlist

\begin{tabular}{|c|c|c|c|c|c|}
\hline \multicolumn{6}{|c|}{ Tier 2 Watchlist Placement $(\mathbf{N}=14)$} \\
\hline Country & \#cases & Guilty & Not Guilty & Dismissed & Other Charges \\
\hline Belarus & 1 & 3 & 0 & 0 & 0 \\
\hline Belize & 20 & 2 & 1 & 0 & 0 \\
\hline Bolivia & 5 & 3 & 0 & 1 & 2 \\
\hline Bosnia \& Herzegovina & 32 & 4 & 0 & 0 & 0 \\
\hline Cambodia & 11 & 4 & 0 & 0 & 1 \\
\hline China & 4 & 4 & 0 & 0 & 1 \\
\hline Cyprus & 29 & 1 & 0 & 0 & 0 \\
\hline Jamaica & 10 & 1 & 0 & 0 & 1 \\
\hline Kenya & 8 & 1 & 2 & 3 & 2 \\
\hline Marshall Islands & 13 & 1 & 0 & 1 & 1 \\
\hline Panama & 24 & 1 & 1 & 1 & 0 \\
\hline Sri Lanka & 1 & 1 & 0 & 0 & 0 \\
\hline Ukraine & 21 & 21 & 0 & 0 & 0 \\
\hline MEDIAN & 4 & 3 & 0 & 0 & 0 \\
\hline AVERAGE & 5.3 & 3.62 & 0.31 & 0.46 & 0.62 \\
\hline
\end{tabular}

Tier 3 Placement. The 6 countries in the Tier 3 category had an average of 4.33 cases presented with an average number of guilty verdicts of 2.83 (see Table 5). Thailand presented 32 
cases of human trafficking but found only 4 with a guilty verdict. Venezuela presented 4 cases and found all to have a guilty verdict.

Table 5

Data for Countries in Tier 3

\begin{tabular}{|l|c|c|c|c|c|}
\hline \multicolumn{7}{|c|}{ Tier 3 Placement (N = 6) } \\
\hline \multicolumn{1}{|c|}{ Country } & \#cases & Guilty & Not Guilty & Dismissed & Other Charges \\
\hline Malaysia & 1 & 3 & 0 & 0 & 0 \\
\hline Republic of Korea & 20 & 2 & 1 & 0 & 0 \\
\hline Russian Federation & 5 & 3 & 0 & 1 & 2 \\
\hline Thailand & 32 & 4 & 0 & 0 & 0 \\
\hline Uzbekistan & 11 & 4 & 0 & 0 & 1 \\
\hline Venezuela & 4 & 4 & 0 & 0 & 1 \\
\hline MEDIAN & 3 & 2 & 0 & 0 & 1 \\
\hline AVERAGE & 4.33 & 2.83 & 0 & 0 & 1.5 \\
\hline
\end{tabular}

\section{Discussion}

This data shows a hopeful effort by countries to fight human trafficking. With 50 of the 91 countries demonstrating an above average (71\%) conviction for guilty verdicts, the concern of implementing human trafficking laws seems smaller than most would hope. However, when the conviction rate for guilty verdict is compared by tier placement, we see that countries on the Tier 2 Watchlist and Tier 3 placements have a higher rate of achieving a guilty verdict for human trafficking than countries on the Tier 1 and Tier 2 placements. This would seem to indicate that these countries are having greater success with implementing the laws.

The percentage of guilty verdicts was influenced by the total number of cases. So while the countries in Tier 2 Watchlist and Tier 3 categories had higher percentage of guilty verdicts, they had a lower median and average number of cases. The median number of cases for Tier 1 countries was 10 and the average was 18.07, and the median number of cases for Tier 2 countries was 5 and the average was 13.18. These numbers are higher when compared to the average and median number of cases in the Tier 2 Watchlist and Tier 3 categories, especially when looking at 
the average. Tier 2 Watchlist countries had a median of 4 cases and an average of 5.3 cases, and Tier 3 countries had a median of 3 cases and an average of 4.33 cases. This would seem to indicate that as countries decline in their tier placement, they pursue fewer cases, which in turn can indicate a lack of implementing human trafficking laws. The U.S. Department of State (2011) determines the countries’ placement based on their cooperation with the minimum standards. While the U. S. determines what these standards are, the collected data offers a possible explanation of how the countries are meeting or failing to meet these standards.

Considering that the punishment of the trafficker is part of the minimum standards, their average and median number of cases could be a determining factor in their tier placement.

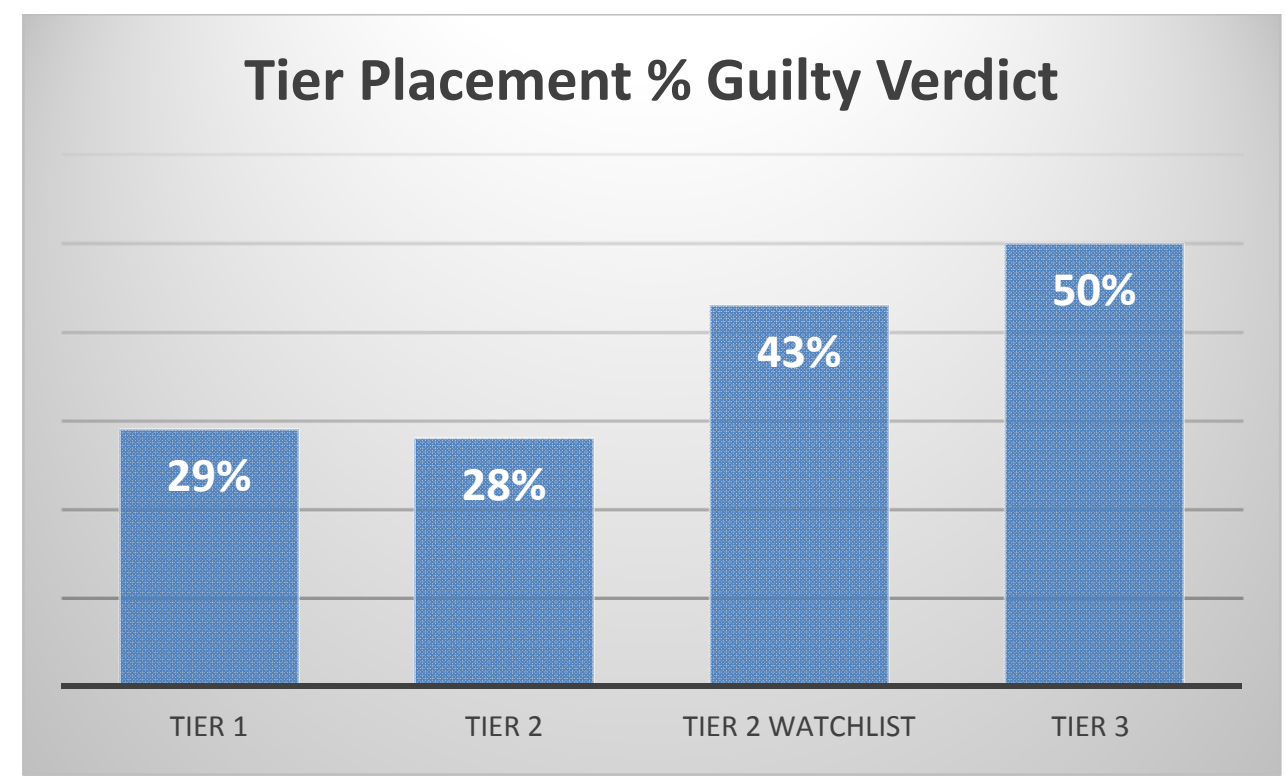

Figure 2

Tier Placement and Percentage of Guilty Verdict How does the structure of the laws affect the number of cases?

The trafficking in persons laws of Bangladesh, the United States, Thailand, and the UAE were briefly examined to determine if there was a correlation between the drafting of laws on 
human trafficking and the number of cases being prosecuted. Bangladesh has structured the Prevention of Oppression Against Women and Children Act 2000 in general terms; meaning there is not much specification on the meaning of terms or how the punishment is handed down. It also did not adopt the global definition of trafficking in persons The TVPA of the United States on the other hand is very detailed and descriptive. It includes pages and pages of explanations of the law, including the definitions, punishments, and specifications. With this comparison it could be assumed that the United States has more cases because their efforts in the drafting of the law have aimed to increase punishment, provide protections for victims, and encourage international cooperation in fighting human trafficking. This assumption can be problematic however because the level of specification of laws is not a direct correlation of the number of prosecuted cases. This is evident from the information gathered on the UAE. Federal Law No. 51 is less descriptive than the TVPA, but it is more explanatory of its definitions and punishments than Bangladesh. Yet Bangladesh has more cases than the UAE.

What could have an effect on the number of cases is how well these laws are implemented. One could believe that once human trafficking was criminalized and punishment for its violation was outlined, efforts would be made to enforce such laws, but it is untrue. Implementation, through the punishment of traffickers, is a necessary tool for fighting human trafficking. If we look at the number of cases pursued, the numbers are very low. Some cases, such as Japan, date back to the 1990s. Using Japan as an example, we can see that 3 cases in a span of 18 years are considerably low. The same can be said for countries that have a higher number of cases. For example, the United States has had 149 cases, but these span from 19812013. This supports our prediction that the implementation of human trafficking laws is weak. 


\section{Bangladesh}

Though human trafficking has a large effect on Bangladesh (Joarder \& Miller, 2014), very little has been done by the government to tackle this issue. They do not comply with the minimum standards of the protocol, but their refusal to accept the global definition of trafficking in persons (UNODC, 2015), and the numbers of cases brought to prosecution do not show progression by the government towards fighting human trafficking. Bangladesh drafted the Human Trafficking Deterrence and Suppression Act in 2012, which offered some evidence that they are trying to confront the issues of trafficking, yet it still lacks finalization and implementation (United States Department of State, 2013). This act has in no way produced more convictions, as it is shown in the data, nor has it done much to provide protection and support for the victims.

\section{United Arab Emirates}

The UAE has long had issues with labor trafficking and sex trafficking (United States Department of State, 2013). While there have been reports stating that the UAE has increased its efforts in fighting sex trafficking, they have failed to address labor trafficking. Not only have they not provided reports on their improvements of labor trafficking, but there is very little effort to address human trafficking dealing with males. The UAE passed a law banning the “employment” of children as camel jockeys in 2002, which included anyone under the age of 16 and under 100 pounds (Freedom House, 2006). However, there are reports that show that the practice of using very young children for camel racing is still occurring (Perskie, 2004). The move of the UAE from Tier 3 to Tier 2 Watchlist and their label of being a model for the region may be credited to political motives rather than their efforts to fight trafficking of camel jockeys; 
the people running the racing businesses are the leaders of the UAE, and in turn for their help, such as lobbying and being a staging route in the Persian Gulf during the Iraq war, the United States stopped putting pressure on them to improve human trafficking conditions. Their lack of reporting and the political controversy that surrounds the UAE could be a contributing factor to the lack of information available.

What makes a difference?

A couple of explanations are offered for the variation in the number of cases of countries. One is the country’s participation as a party of the Protocol to Prevent, Suppress, and Prevent Trafficking in Persons. Thailand and the United States are both signatories of the PPSPTP, and they have a higher number of cases than do Bangladesh and the United Arab Emirates, who are not signatories. Countries who sign on as parties of the PPSPTP accept the treaty and agree to create legislation that support the provisions outlined in it (Lee, 2011). This includes acceptance of the definition, criminalizing human trafficking, and punishment of the trafficker. This comparison goes beyond the four countries included in this study, especially when we consider the countries with a high number of cases. Brazil, Slovakia, and Moldova are just a few of the countries that showed high number of cases and are also signatories to the PPSPTP.

The United States has had a large number of cases in comparison to all the countries due to their initiatives to go beyond what the PPSPTP requires the signatories to do. For example, the U. S. has not only ratified the TVPA to conform to the growing needs to combat human trafficking, but has created multiple tools to collect trafficking in person’s research. This includes the Trafficking in Persons Report and the tier placement of countries and the states 
within the United States. The U. S. has also created programs to provide assistance to victims and to train law enforcement on human trafficking (Wilson, Walsh, \& Kleuber, 2006).

Another explanation for the variation in the number of cases of countries is the cooperation of the police to pursue and arrest those who violate the law. In some cases, such as Bangladesh, corrupt law enforcement work with the organized crime groups to traffic women and children in-between countries' borders (Paul \& Hasnath, 2000). It can be assumed that this leads to under reported cases because the "enforcers" of the law are the ones breaking the law, and it could also discourage people to report the crimes because of uncertainty of the willingness of law enforcement to help.

\section{Conclusion}

\section{Limitations}

As with most research, the current study had limitations. The database used for this study only recorded cases that presented all three of the elements of the internationally agreed upon definition of trafficking in persons; the act, the means, and the purpose. Although some special cases that lacked this requirement were included, the majority were not. This not only narrowed our scope of the number of cases being pursued, but it gave an unfair advantage to the countries that adopted the international definition. It is not clear why this standard was set, but a possible explanation may be that this global definition allows for uniformity, and it provides a "true" definition of what should be considered human trafficking. It is unclear whether the data would have changed if the standard was not set, but this could be further explored in future studies by analyzing specific countries through other databases. 
Additionally, the narrow scope of this study did not allow for examination of how human trafficking is reported in different countries or how cultural beliefs and economical status affect implementation. The future research of this information could be used to explain not only the low number of cases, but the differences in the number of cases between specific countries.

\section{Implications}

This study substantiated that some countries, such as the UAE and Bangladesh, lack implementing the international laws as well as domestic laws on human trafficking through prosecuting traffickers. The Protocol to Prevent, Suppress, and Prevent Trafficking in Persons (PPSPTP) was passed to guide countries in criminalizing human trafficking, setting out punishments for the offenders, collecting research on the issue, and helping victims. Countries can become signatories of this protocol by choice and there are currently 117 signatories (UNODC, 2008). Although countries are signatories, they don’t always fully comply with the treaty. For example, the data shows that Thailand is in the Tier 3 category, but they are one of the signatories of the PPSPTP. The PPSPTP does not outline any punishment or penalty for countries who do not comply with the treaty. There has also been no pursuit by the international court to punish countries for not showing efforts to combat human trafficking. If punishment and penalties for non-compliant countries were amended to the PPSPTP, the issue of implementing human trafficking laws could be improved.

This quantitative study demonstrated the importance of implementing human trafficking laws, especially when discussing the prosecution of the traffickers. It was narrow in scope, but can be used as a stepping stone for future research on how to improve implementation of human trafficking laws, domestically and internationally. 


\section{References}

Abramson, K. (2003). Beyond consent, toward safeguarding human rights: Implementing the United Nations Trafficking Protocol. Harvard International Law Journal, 44(2), 473502.

Bales, K., \& Soodalter, R. (2009). The slave next door: Human trafficking and slavery in America today. Berkeley: University of California Press.

Clawson H.J., Dutch, N., Lopez, S., \& Tiapula, S. (2008). Prosecuting human trafficking cases: Lessons learned and promising practices (223972). Washington DC: U.S. Department of Justice.

Council of Europe Convention on Action against Trafficking in Human Beings. May 16, 2005. Warsaw. Available at http://conventions.coe.int/Treaty/en/Treaties/Html/197.htm Freedom House. (2005). Freedom in the World 2006 - United Arab Emirates, 19 December 2005, available at: http://www.refworld.org/docid/473c55a02.html [accessed 4 March 2015].

Gooey, J. (2008). Human trafficking. Criminology \& Criminal Justice, 8(4), 421-442.

Harvard School of Public Health. (2000). The Parliament of Bangladesh: Act No VIII of 2000. Retrieved from http://www.hsph.harvard.edu/population/trafficking/bangladesh.traf.00.pdf

International Labour Organization. (2015). Forced labour, human trafficking and slavery; facts and figures. Retrieved from http://www.ilo.org/global/topics/forcedlabour/langen/index.htm

Joarder, M. A. M., \& Miller, P. W. (2014). Empirical evidence on human trafficking and migration-debt contracts in Bangladesh. Journal of Development Studies, 50, 3. 
Lee, M. (2011). Trafficking and global crime control. Thousand Oaks, California: SAGE Publications.

Legislative and Parliamentary Affairs Division. (2010). The constitution of the people's republic of Bangladesh. Retrieved from http://bdlaws.minlaw.gov.bd/print_sections_all.php?id=367

National Committee to Combat Human Trafficking. (2006). United Arab Emirates federal laws and treaties. Retrieved from http://www.nccht.gov.ae/en/menu/index.aspx?mnu=cat\&PriMenuID=14\&CatID=10

Paul, B.K., \& Hasnath, S.A. (2000). Trafficking in Bangladeshi women and girls. Geographical Review, 90(2), 268-276.

Perskie, J. (2004). Sports of sheikhs. HBO Real Sports. New York.

Polaris Project. (2015). Human trafficking statistics. Polaris Project. Retrieved from http://www.cicatelli.org/titlex/downloadable/human\%20trafficking\%20statistics.pdf

Protection Project. (2010). The Anti-Trafficking in Persons Act B.E 2551 (2008). Retrieved from http://www.protectionproject.org/wp-content/uploads/2010/09/Thailand_AntiTrafficking-Law_2008.pdf

Protection Project. (2010). United Arab Emirates Trafficking Law (2006). Retrieved from http://www.protectionproject.org/wp-content/uploads/2010/09/United-ArabEmirates_Trafficking-Law_2006-Ar+En.pdf

Protection Project. (2015). U.S. anti-trafficking legislation. Retrieved from http://www.protectionproject.org/resources/law-library/u-s-anti-trafficking/ United Nations on Drugs and Crime. (2015). Human trafficking case law database. UNODC. Retrieved from http://www.unodc.org/cld/index.jspx 
United Nations Office on Drugs and Crime. (2008). Chapter XVIII Penal Matters. Available at http://www.unodc.org/unodc/en/treaties/CTOC/countrylist-traffickingprotocol.html

U.S. Department of State. (2011). Trafficking in persons report 2011. Retrieved from http://www.state.gov/j/tip/rls/tiprpt/2011/164236.htm

U.S. Department of State. (2014). Trafficking in persons report 2014. Retrieved from http://www.state.gov/j/tip/rls/tiprpt/2014/226649.htm

United States Department of State. (2013). Trafficking in persons report 2013 - Bangladesh, 19 June 2013, available at: http://www.refworld.org/docid/51c2f3d818.html [accessed 28 February 2015]

United States Department of State. (2013). 2013 Trafficking in Persons Report - United Arab Emirates, 19 June 2013, available at: http://www.refworld.org/docid/51c2f37a3e4.html [accessed 4 March 2015]

Wilson, D.G., Walsh, W.F., \& Kleuber, S. (2006). Trafficking in human beings: Training and services among US law enforcement agencies. Police Practice \& Research, 7(2), 149160. 